\title{
On the application of case teaching method in Business English Teaching
}

\author{
Yinpin Huang ${ }^{1, \text { a }}$ \\ ${ }^{1}$ School of Foreign Languages, Jingchu University of Technology, Jingmen , 448000 \\ ahyinpin@163.com
}

\begin{abstract}
Keywords: Business English teaching; case teaching method; advantage; method
Abstract. under the background of economic globalization, social economic development of our country's growing prosperity, foreign trade is more and more frequent, as the status of the world's common language of English in the world is more and more important, business English has become a necessary technical and economic professionals must master one of the. Therefore, our country has paid more and more attention to business English teaching. With the College Business English teaching reform, case teaching method of business English teachers won the admiration and trust, this teaching method is mainly to explain with the real case of knowledge related to English speaking English, compared with the traditional teaching method, more authenticity, and the teaching method also pays attention to the interaction between the teacher and students and exchange. This paper introduces the concept of case teaching method. Expounds the application of case teaching method in Business English teaching. Finally, focuses on the application of case teaching method in Business English teaching methods, hoping to be able to help to improve the level of business English Teaching in Colleges and universities.
\end{abstract}

\section{Introduction}

General English Teaching for students, mainly in order to enable students to master the reading, writing and translation ability of the five, the same business English teaching to students, students are required to master must be carried out on the five kinds of ability, but the biggest difference exists between the two is that the students pay more attention to the teaching of business English in a business environment for the ability of using english. Therefore, in order to improve the functional level of students' application of English, China has carried out a series of reforms in the teaching of business English in Colleges and universities. The application of case teaching method to the reform of business English Teaching in Colleges and universities, no doubt can play a multiplier effect. This paper is to explore the application of case teaching method in Business English teaching.[1]

\section{Overview}

2.1The theoretical background of case teaching method

Case teaching method first appeared in ancient Greece, is a famous philosopher Socrates. But the first country to use this approach was the United states. In the American law school, the teacher explained in theory of legal knowledge, to enable students to understand the rather obscure legal regulations, enumerated the laws of the real case to assist in teaching, to attract students' attention at the same time, and let the students learn the ability of how to apply the law in the real situation. Since then, this teaching method has been spread. The Harvard Business School in the United States will also be applied to the teaching of this approach, and achieved good teaching results. Case teaching method combines theory with practice, and is commonly used in various fields.

2.2 The concept of case teaching method

Case teaching method, as the name suggests, this is a case as the core of teaching methods. The case itself is to put in place a teaching situation for the students, the role of the teacher in the role of the designer and the encouragement, to guide students to actively discuss the situation, and ultimately give their own answers.

\subsection{Case material selection}

In the use of case teaching method in the teaching process, the use of teaching materials is not a rigid teaching material, but vivid and real case material. The choice and elaboration of the case material is 
not simply depicted, but a representation of the actual scene. In Business English teaching, to teaching business scene simulation, let the students in real situations, analysis of case materials, in order to help students better understand the relevant knowledge of English, and master the ability to use English in the teaching situation in business. At the same time, business English teachers must according to the learning needs of students and the current development of the times change, at any time of the case teaching materials selected for update, so as to avoid the disconnection of case teaching materials and textbooks phenomenon.[2]

In case teaching, case selection should follow the following points: first, the case must be real, that is to say the case should be based on objective facts, then the real scene representation or description of the case, and not able to let teachers free to write and fiction, because the real case can be more to attract students, stimulate students' interest in learning english. At the same time, the case has the characteristics of authenticity, so that students will be associated with the English language knowledge and social reality, is conducive to their understanding of society. Second, the choice of teaching cases must be vivid, on the basis of respecting the authenticity of the case, the case should also be inventive. This requires teachers in the case of reproduction, as far as possible the use of literary techniques. For example, through the description of the scene, psychological portrayal, dialogue and other ways to increase the weight of subdivision, so that students feel in their habitat. Third, the selection of teaching cases should have the characteristics of diversity. If there is no case of violent conflict and tortuous plot, it will not play a useful teaching effect. If the teacher listed in a business English teaching, the students one can see through the answer, then this case will lose the value of discussion for this case, students will not have a great deal interest. Therefore, the more diversity of the selected cases, the more valuable, the more worthy of study. Fourth, the case should be appropriate for students to learn. Business English Teaching in Colleges and universities is not only for business students, but also some non business students also need to learn business English courses. Therefore, the selected cases to meet the needs of students. For non business majors, they have no business because of his theoretical knowledge more, so the choice of business English teaching case, should avoid involving too many business English knowledge, so they canunderstand and learn.

\section{The application of case teaching method in Business English Teaching}

Compared with the traditional teaching method of case teaching in Business English French, because in the process of teaching, the real teaching case to carry on the resentment scene, let the students in situations, to stimulate students interest in learning. In the actual teaching process, students can be more active and active participation in teaching, which shows that this teaching method is more vivid and flexible, more easily accepted by the students. The purpose of the application of case teaching method in Business English teaching is to enable students use the theoretical knowledge to solve the practical problems encountered in the business work. Therefore, the application of case teaching method is of great importance in Business English teaching. Generally speaking, the application of case teaching method in Business English Teaching in Colleges and universities has the following advantages:

3.1 High authenticity, promote students to think actively

In the business English teaching process in the past, the traditional business English teaching methods mainly applied in the theory teaching of inculcation, students learn in a passive position, are not able to truly participate in the process of learning English to. But with the English teaching reform, applying case teaching method to business English teaching, due to the selection of teaching cases based on objective facts, authenticity is relatively high, so in the case of flashbacks, teachers can arrange students according to the case in role play, play in the role of the learning process among the students to think of themselves as a participant, and for the situation involved in the problem, give their own ideas and answers. Therefore, the application of case teaching method in Business English teaching can make students in the situation, deepen the students"s knowledge and understanding of business English knowledge, and promote the students' active thinking.[3] 


\subsection{Broaden students' horizons, enrich students' knowledge}

Because the selected teaching cases are true, so students to master the knowledge of teaching content according to the case of all materials, in preparation for the work must be carefully related information to find work after class, are required to summarize and integrate knowledge. In the process of access to information and the integration of knowledge, the students can broaden their horizons, but also because of the expansion of business English learning, enrich the students' knowledge.

3.3 Enhance the interaction between teachers and students, help students to show themselves In the traditional teaching of business English, mainly adopt the teaching mode for teachers and students to listen carefully on the table ", this kind of traditional teaching method in classroom teaching atmosphere is relatively heavy, little interaction between teachers and students, students also have to show the advantage of self. Nonetheless, through the application of case teaching method, students can discuss the process to fully express their views, in the exercise of their language ability and logical thinking ability at the same time, they also help to show the self.

3.4 Conversion of the role of teachers, teachers and students in an equal position

In the outmoded business English teaching, teachers have to superior attitude to teaching students, more often, teachers play the role of control and evaluation. However, after the application of case teaching method in Business English teaching, the role of teachers in teaching has changed. This change in the teaching role, the teacher will fall, let the "altar" between teachers and students is equal, which is more conducive to students in English learning.

\section{Case teaching method in Business English Teaching in the actual English strategy}

The application of case teaching method in Business English teaching, there is no fixed team application model of business English teachers can according to the personal needs of school teaching business English Business English syllabus requirements and students, but the process of business English Teaching in the use of case teaching method, there are several steps is absolutely can not be neglected. This is the key of the case teaching method, we explain below:

4.1 Preparation of teaching cases

In the preparation stage, business English teachers first need to determine the direction of the case according to the specific requirements of the goal of business English teaching, school teaching content and students' learning of business English, and on this basis to determine the type of case. Second, business English teachers must conduct in-depth understanding of business English Teaching of English knowledge, and collect some auxiliary teaching materials in business English teaching, the business English teachers need to consider the suitability of the selected teaching cases, whether for business English students. In passing to the case teaching method can achieve good effect of English Teaching in Business English teaching, must do the following, first, after determining the goal of business English teaching, then the choice of case. Second, select the case to be taken into account the actual situation of the students, according to the needs of students and the characteristics of the study to choose the right case. Third, the case should be consistent with the times, and close to the real life, the individual case is more authentic, more able to attract the interest of students. Fourth, the contents of the case must be real and vivid, but also clear and easy to understand, so that students can be constructive thinking and Research on the case.[4]

\subsection{Good case analysis and preparation}

In the teaching of business English, business English teachers use the case teaching method, first of all to the case material prepared for students, teachers can prepare more than a few cases, let students choose one of the most interesting case studies. The reason why we let the students choose a case study, and that of other cases is rejected, but to allow the students according to their own interest to learn, Einstein once said: "interest is the best teacher", only students interested in, can stimulate their study enthusiasm, they also can with the enthusiasm of more serious research on the case. Secondly, when students choose to end the case, teachers can provide appropriate information to the students, and teachers should accord to the characteristics and the English level of the students will be divided into class 3-6 members of the group results. The members of the group should be diversified, so that they can hear the voices of different opinions in the case analysis and discussion. Finally, teachers 
should allow students to hold their own activities, case analysis and discussion, not to interfere with the students.

4.3 Focus on team work

After a period of analysis and discussion, the teacher asked each group to elect a group of Representatives, and a team of representatives to the group of people on the final discussion of the case published. Published time should be controlled within 10-15 minutes, after the group represents the end of the speech, other team members can according to the problems in the case of the questions, ask the group representatives to give a reasonable explanation, at this time, members of the group can also substitute group on behalf of answering questions. In the process of group discussion, the students have the ability of language expression and logical thinking. The teachers in this stage, as the organizers and the role of the guide, the teacher is to guide students in order to gain a better understanding of the case.

4.4 Do a good job summary

After the application of the case teaching method, the business English teachers should carry on the corresponding summary and the development of business English knowledge. The focus of this paper is mainly on the general idea of the case study, the discussion of the students, business English knowledge involved in the case. In summary, on the performance of students teachers should give affirmation and encouragement, stimulate their enthusiasm for learning, but also pointed out the deficiencies in the case discussion, such as the idea is too narrow, too one-sided view, discuss the atmosphere is too low, the students lack of initiative and so on. The main purpose is to assist students learn to self reflection, but also help in the future application of case teaching method can be further, play a better teaching effect. After summing up, teachers should also expand the knowledge of business English, broaden the knowledge of students, so that students learn more knowledge of business english.

\section{Acknowledgements}

1.Science of Education key Programs of the Twelfth Five-year Plan of Hubei in 2014, No. 2014A038, "the Research o n Applied Personnel Training Mode in Business English of Local College Based on Transition” , Researching Project, Sequence 2

2.Teaching Research Program of Jingchu University of Technology (JCUT) in 2016, JX2016-36, the Research on Mixe d Teaching Model of Business Comprehensive English Based on MLI, Researching Project, Sequence 3

\section{Summary}

In summary, the application of case teaching method in Business English teaching has good teaching effect, it can enhance the students to master the knowledge of the theory of business English, also let the students learn how to ability of business English knowledge is applied to solve the practical problems in the. Although this method has some advantages, it does not mean that it can completely replace the traditional teaching methods. So in the course of business English teaching, teachers should be based on the goal of business English teaching and learning needs of students, the selection and application of case teaching method properly, the only way to make the business English Teaching in Colleges and universities play a multiplier effect.

\section{References}

[1]Esteban A A, Cañado M L P. Making the case method work in teaching Business English: a case study[J]. English for Specific Purposes, 2004, 23(2):137-161.

[2]Liu H L, University S N. A study of case method in college business English teaching[J]. Journal of Changchun Institute of Technology, 2015. 
[3]Yao J G. Application of the situational teaching and case teaching in business English teaching in higher vocational colleges[J]. Journal of Jiamusi Education Institute, 2014.

[4]Liao S Q, Yan J, Xie Y B. The Application of Role-play Method Based on the Real Case in Class Teaching of Business English Negotiation_- - Taking Guangzhou Institute of Railway Technology as an Example[J]. Journal of Southern Vocational Education, 2013. 